\title{
Currency and the Stability of People's Purchasing Power in Indonesia through Al-Maqrizi's Review
}

\author{
Mirza Purta Ashari
}

Sunan Kalijaga Islamic State University

Email: asharimirza8@gmail.com

\begin{tabular}{ll}
\hline Keywords: & Abstract: \\
\hline $\begin{array}{l}\text { Money, Purchasing } \\
\text { Power, Al-Maqrizi }\end{array}$ & $\begin{array}{l}\text { The presence of money has become an important part of people's daily lives, as well } \\
\text { as the purchasing power of the people as an important element in the smooth economic } \\
\text { cycle. The emergence of money came from the development of transactions that } \\
\text { initially used barter which was later replaced by currency as a medium of exchange } \\
\text { for international trade. Money management can be done by the government by } \\
\text { controlling money in the form of monetary policy. This policy was a benchmark for a } \\
\text { country's economy, when the state was able to control money well, the people's } \\
\text { economy was also prosperous. The qualitative descriptive approach was used in this } \\
\text { study. This article tried to provide views and discussion material to what extent the } \\
\text { concept of monetary policy according to Al-Maqrizi and the implementation of his } \\
\text { thinking was used in policymaking on people's purchasing power. The result of this } \\
\text { research was that the concept offered by Al-Maqrizi was a concept of money that led } \\
\text { to a moral, just, humane, and prosperous economy. }\end{array}$
\end{tabular}

\begin{tabular}{ll}
\hline Kata kunci: & Abstrak: \\
\hline Uang, Daya Beli, Al- & $\begin{array}{l}\text { Kehadiran uang telah menjadi bagian penting dari kehidupan masyarakat sehari-hari, } \\
\text { Maqrizi }\end{array}$ \\
& $\begin{array}{l}\text { serta adanya daya beli masyarakat sebagai unsur penting dalam kelancaran siklus } \\
\text { perekonomian. Munculnya uang berasal dari pengembangan transaksi yang awalnya } \\
\text { menggunakan barter yang kemudian digantikan dengan mata uang sebagai alat tukar } \\
\text { perdagangan internasional. Pengelolaan uang dapat dilakukan oleh pemerintah dengan } \\
\text { cara mengendalikan uang dalam bentuk kebijakan moneter. Kebijakan inilah menjadi } \\
\text { tolak ukur perekonomian suatu negara, ketika negara mampu mengendalikan uang } \\
\text { dengan baik maka perekonomian masyarakat juga sejahtera. Pendekatan deskriptif } \\
\text { kualitatif yang digunakan pada penelitian ini. Artikel ini mencoba memberikan } \\
\text { pandangan serta bahan diskusi sejauh mana konsep kebijakan moneter uang menurut } \\
\text { Al-Maqrizi serta implementasi pemikirannya yang digunakan dalam pengambilan } \\
\text { kebijakan terhadap daya beli masyarakat. Hasil daripada penelitian ini ialah konsep } \\
\text { yang ditawarkan oleh Al-Maqrizi merupakan sebuah konsep uang yang mengarahkan } \\
\text { pada ekonomi yang bermoral, adil, manusiawi, dan sejahtera. }\end{array}$ \\
\hline & Received: September 28, 2020. Revised: June 22, 2021. Accepted: June 29, 2021
\end{tabular}

\section{Introduction}

All economic activities cannot be separated from trade transactions using means of exchanging goods and services, namely money. As an important instrument in economic activities, the presence of money is vital especially for obtaining goods, services, and other life needs. The emergence of money stemmed from the development of transactions that initially used barter which was later replaced with currency as a means of international trade exchange.

Such activities have occurred before and after the time of Islam, at the time of the Prophet himself money had been used as a means of payment that was Persian dirham (silver) and Roman dinar (gold) 
was still in their original form, but there has been no change or marking. During the Islamic era itself has known money as a means of exchange also called dinar (gold money). The first to impose dirhams and dinars in the Islamic state during the Umayyad caliphate, Abdul 13 Malik bin Marwan in 74 AH or around $696 \mathrm{AD}$, made a redesign of the modern dinar currency in his time Esposito (Al-Maqrizi, 1998; Esposito, 1999).

In its development, the circulation of money is required supervision related to its quantity in the community. When printing money, the government should pay more attention to the use of currency in future businesses. This neglect can lead to an imbalance in printing and production activities, which will lead to a decrease in the purchasing power of real money (Ghazali, 1991). Government or central bank policies in printing money that serve to stimulate economic activity in a country can change purchasing power from the present to the future (Ilyas, 2016). The increase or decrease in people's purchasing power is directly related to the amount of money or income owned by the community.

People who have more money tend to have high purchasing power, but on the contrary, if they have less money or income then the purchasing power of the community will decrease as well. This often happens during religious holidays that make people's purchasing power increase but not accompanied by an adequate supply of goods. In the current context, the function of money has become a commodity that is completely irrelevant to the actual function of money. In various cases related to the function of money that is no longer as a means of payment or means of exchange but as a business that can generate greater profits as concrete examples of authors encountered tracking (dollar exchanges) and also small money exchange on during religious holidays. Suar (2020) explained that the existence of money, one of which is the rupiah at this time is still relatively stable and there is no increase in the value of the rupiah currency in Indonesia, but the possibility of the rupiah decrease at a time of reduced investor confidence.

Based on research from Hernaningsih (2018), the amount of money circulation and stable inflation rate can facilitate economic actors in decision-making and increase the purchasing power of the community. According to Al-Maqrizi, the government should take the stance that currency printing should be based on a balanced ratio of the number of currencies to the number of transactions to create a reasonable price. To solve the problem, Baitul Maal is established to regulate the circulation of money in the community. At present, it can be said that Baitul Maal is represented by an institution with a larger and wider scope, namely the presence of Bank Indonesia as a monetary policy holder in Indonesia.

Futhermore, Abdullah (2020) stated that the deterioration of the value of money and purchasing power can occur if the government issues the wrong monetary policy. Monetary policy should not ensure stable prices, but targets the stabilization of the circulation of money amounts, which indirectly impacts the stability of the currency value and the purchasing power of the people long term (Abdullah, 2016). One of the recent monetary policies conducted by the state of Indonesia through Bank Indonesia is issuing special money commemorating the 75th Anniversary of the Republic of Indonesia. The decisionmaking of printing the new currency has been through various considerations to minimize the economic impact on society. This is because the presence of new money makes the enthusiasm of the public in exchanging new money to be increased due to the limited amount of money spent by Bank Indonesia.

Based on the explanation above, this article tries to provide an insight into the extent to which the concept of monetary policy and the stabilization policy of people's purchasing power is reviewed through al-Maqrizi's thinking.

\section{Research Method}

This research used a qualitative method that were often used in several disciplines, especially those directly related to natural sciences and social sciences (Babbie, 2014). Furthermore, this research was followed up through library research that was used as a reference by using secondary data obtained from library literature, either in the form of articles, journals, books, or results from previous research 
(Nazir, 1988). This was based on theories and findings from previous studies collected and further correlated with current social conditions, so that the method of data analysis used in this study used descriptive analysis. The author tried to describe al-Maqrizi's view data on the concept of currency and described his view as analytical material.

\section{Results and Discussion}

\section{a. Al-Maqrizi's Social Condition and His Intellectual Works}

Taqiyuddin Abu al-Abbas Ahmad bin Ali bin Abdul Qadir al-Husaini or better known as AlMaqrizi was born in Barjuwan village, Cairo, in 766 AH (1364-1365 AD). Maqarizah's own nickname came from his family, who lived in a village located in the western City of Ba'labak Damascus (Syria), which now belonged to the Lebanese state. Therefore, he was better known as al-Maqrizi (Islam, 1999)

At the age of 22, Al-Maqrizi began to serve in the Mamluk dynasty as an employee in Diwan alInsya (a kind of secretariat of state) in $788 \mathrm{AH}$ (1386 AD). Later, he was appointed as qadi's deputy at the office of the supreme judge of the Shafi'i sect (asy-Syayyal, 1967). After that in 791 AH (1389 AD), Al-Maqrizi's career continued with the appointment of muhtasib (market supervisor, a kind of market head) by Sultan Barquq in Cairo for two years. On this assignment, Al-Maqrizi began to know a lot about various conditions of market problems, trade, and mudharabah, so that the focus of his attention related to the prevailing prices, the origin of money, and the rules of scales.

The social conditions at the time of al-Maqrizi's life were going through a difficult time. This was due to the poor government of Egypt at that time which was dominated by corruption, collusion, nepotism, and inefficient administration. The crisis was exacerbated by a significant rise in inflation. The policies imposed by the Egyptian government at that time benefited only one party, namely its government officials, who directly the Egyptian people were victims of an impartial policy to the people.

Al-Maqrizi suggested that the recovery of the economic crisis was done without having to take actions and policies that had a continuous impact on the interests of the people and reduce the level of welfare in general. The form of prolonged losses was the government's lack of responsibility in the regulation of economic recovery at the time of a major event such as natural disasters or ethnic conflicts (Nasution, 2007). Al-Maqrizi discussed the role of money and inflation based on his experience as a muhtasib (market supervisor), a discussion that soughted to correlate the two. Al-Maqrizi in his work wanted to prove that inflation faced in the period 806-808 $\mathrm{H}$ had a difference from inflation experienced throughout Egyptian history (Karim, 2017).

Al-Maqrizi was very productive during his life in writing various fields of science. All of his work consistsed of small and large books, small books containing descriptions of various fields of science outside history, while Al-Maqrizi's work in the form of a large book, Al-Syayal is_subdivided into three categories. First, a book that discussed the history of the world. Second, a book that explained the history of general Islam. Third, a book describing the egyptian sejah during the Islamic period. From his many intellectual works, the discussion of al-Maqrizi's economic thinking was only found in the Book of Risalah fi al Nuqud Islamiyyah and ighatsah al ummah bi Kasyfil Gummah (Alioucha, 1994).

\section{b. People's Purchasing Power in Al-Maqrizi Theoretical Review}

Reflecting on the monetary situation during the time of Al-Maqrizi who lived during the reign of Sultan Shalahuddin Al-Ayyubi in Egypt. Their policy was to print currencies that were of a lower quality than the currency in circulation. According to al-Maqrizi, the government needed to pay more attention to print money to continue to be used in the community. The policy was inseparable from each of the different leaderships in implementing policies related to printing the form, quality, and value of dirhams and dinars. The phenomenon became an exhortation from Al-Maqrizi to traders not to be deceived by the increase in nominal profit. Traders can realize as producers to make a big profit, but while as 
consumers they did not benefit (Iqbal, 2012), so that people at that time preferred good quality money to keep, and poor-quality money was used in transactions.

The recklessness of the government at that time led to an unbalanced increase in money printing related to production activities that caused the purchasing power of money in the community to decrease. The problem of declining purchasing power was not only related to the problem of printing the quality of money but also related to inflation that occurs. According to Al-Maqrizi with the presence of poorquality money created continuously will be inversely proportional to the decrease of good quality money in society (Vaish, 2009). The purchasing power of money in the community decreased due to the circulation of poor-quality money dominated and the value of money used by the community indirectly decreased.

These phenomena caused economic unstable in the government of Sultan Shalahuddin al-Ayyubi. The injustice that occurred at that time made the public's interest in using and transacting with money reduced. As a result of policies carried out based on the interests of government officials only, so that the real purchasing power of money related to the circulation of two quality money was very detrimental to the people so that production activity became reduced which caused the scarcity of goods and price increases. People's purchasing power over money caused stagnation of economic growth at that time.

\section{c. Al-Maqrizi's Thoughts on Currency}

In the history of Islamic thought itself, Al-Maqrizi lived in a phase in which the intellectual field experienced slow progress in the Islamic world. The reason behind the peculiarity of his economic thinking was his daily life as a Muslim historian who can not be separated from his activities. Almost every form of analysis of problems or problems he faced was done by flashback methods and saw the real condition of a country in its economic field by considering the focused matters related to the increase or decrease in the condition of a government. Thus, Al-Maqrizi had a form of thought that led to positive thinking and became a peculiarity that at that time normative thinking dominated in the second phase of the Islamic world.

Al-Maqrizi also participated in discussing the extent to which money played a role in inflation issues based on his experience as a muhtasib (market supervisor) (Karim, 2001). In his book Ighatsah, he identified fundamentally the extent of the poor political administration at the time with the basis of analysis from Ibn Khaldun. Bribery activities by government employees had become commonplace at the time. As a result, when the employee took office, the tax policy was elevated to prioritize the payment of losses that had been issued for bribery. The policy of printing copper currency (fulus) excessively exacerbated the government's depravity at the time to cover the country's budget deficit.

Al-Maqrizi in expressing his thoughts on money based on his background as a historian judging by the historical trajectory of the currency used by humans.

1) History of Money

Money was first used after difficult trade transactions with the money system in Lydia 570-546 BC. This was the first time to know accurate gold and silver money (Mujahidin, 2007) Al-Maqrizi explained based on the history of the Jahiliyyah Arabs the currency used namely silver and gold from the adoption of the Romans and Persians (Karim, 2017). After Islam, both currencies were still used as muamalah practices that had been determined by the Prophet Muhammad SAW. It was only during the Umayyad caliphate that Islamic money was officially issued in dirhams and dinars, by Caliph Abdul Malik ibn Marwan. Dirhams and dinars had until now become the identity of Islam itself, whereas the first to use it was not Muslims (Ilman, 2001).

The first opinion stated that the creation of dirhams and dinars was as the limit of the existence of money. That was, other currencies such as banknotes cannot be considered as currencies, so only dirhams and dinars can be used as a means of transaction. Maqrizi said, "The money that is the price of the goods sold and the value of the work is only gold and silver." Al-Maqrizi's presentation was seen 
from the use of currency as economic support both in the pre-Islamic period and after, so that he stated that only silver and gold were able to fulfill the objectives of the economy (Karim, 2017). The second opinion stated that money is a matter of terminology. Therefore, money can be a benchmark that was recognized and accepted by the community when viewed from the terminology side. This showed that as long as the activities carried out did not violate the Shari'a and for the benefit of the people. Money earned in any form and material by a leader is not a problem (Ilman, 2001).

Based on the explanation of the historical reality, that only gold and silver can be recognized as a currency regarding the law, standard values, logic, and tradition according to the identification of an AlMaqrizi (Laurence S. Moss, 1996). If the basic material for making currency is not from both silver and gold, it cannot be said to be currency.

2) Dinar and Dirham as a Medium of Exchange

Various policies related to the printing of the dirham and dinar currency as a means of the transaction were determined at every change of ruler and dynasty, some of which prosper the community and became a distinctive feature of the government. For example, the type of dirham that was changed according to the ruler at that time and was reflected in the money. The dinar and dirham were currencies that did not recognize inflation because in Islam itself there was no specific understanding of inflation. The value of the dinar and dirham currencies was always stable and had been justified by Islamic law so that these currencies are highly recommended as an effective medium of exchange. Regarding dinars and dirhams as a medium of exchange, they can be used as official transaction tools in a government monetary system according to Al-Maqrizi's rationale. (Al-Maqrizi T. A.-A., 2007).

Another suggestion put forward by al-Maqrizi was that the quantity of money can be minimized according to the applicable limits according to the level of need in transaction activities only in small fractions (Huda, 2008). In other words, the use of currencies other than gold and silver such as fulus was only allowed in small-scale transaction activities (Islahi, 2013). So that the recognition of the dirham and dinar in circulation as a medium of exchange will increase and the stability of the currency value can be more maintained. The government needed attention in prioritizing the use of dinars and dirhams as a medium of exchange for the sake of the country's economic stability.

3) Fulus as a Dynamic Transaction Tool

Al-Maqrizi's responses regarding fulus as a transaction tool that was only used for small-scale transactions was not without reason. Due to the presence of money, it only has a small currency value and did not even have an intrinsic value. The initial concept of the existence of money was only used as an additional medium of exchange to buy cheap necessities and was not used in large-scale economic transactions.

The low cost of producing foreign currency as an innovation of a new, cheaper medium of exchange prompted the government to print out foreign currency on a large scale. However, too much money circulating as a means of transaction did not have a positive impact on the economy of a country because the intrinsic value of the money itself was so minimal. The quantity of money itself was increasingly circulating in the community, but money was experiencing a rapid increase in its turnover, making it the currency of money that was the most dominant in the world. (Karim, 2017).

4) Currency Creation

During the Abbasid era, a decline in currency printing began to decline in quality. The reduction in the size of the dirham continued until it was reduced to one carat, while the dinar was not reduced as it was. However, the value of the currency is still calculated as before. Al-Maqrizi stated, "In the month of Rajab in $191 \mathrm{H}$, the Hashimiah dinar was reduced by half and continued to decrease until the period ended but its value remained the same." (Al-Maqrizi, 1988).

Al-Maqrizi also argues that the presence of poor-quality money that is created continuously will be inversely proportional to the decrease in good quality money in society (Vaish, 2009). This was 
inseparable from the monetary situation that occurred in $569 \mathrm{H}$, namely the circulation of bad money quantity dominated more than good quality which occurred during the reign of Sultan Saladin al-Ayyubi. At that time, the priority that was prioritized by the community was to save good quality currency and choose to use the poor-quality currency for transactions. Automatically, it causes the worse quality currency to circulate (Karim, 2017).

5) The Government's Role in Currency Stability

There was a correlation between government stability and economic conditions. A bad government had an impact on the country's economic decline. The ongoing stagnant economic growth can occur if state officials committed acts of corruption and the government system, as well as the economic cycle of a country, did not work. If the policies carried out by the government required funds to continue to print without paying attention to the absorption of the real sector in society, currency stability will be disrupted. The consequence of this was that the amount of money in circulation will result in an increase in the price of goods that occurs continuously, which means an increase in inflation (Chamid, 2010).

The loss of public confidence in the government itself regarding the stability of the currency value had reduced public interest in transactions and oppressed the poor. As a result, the quality and quantity of production were reduced so that it can trigger a shortage of goods availability and an increase in the price of goods. According to Al-Maqrizi, the government was directly responsible for maintaining the quality of people's real purchasing power so that currency stability is maintained.

\section{d. Al-Maqrizi's Contribution to Currency and Stability of People's Purchasing Power}

The diversity of people's purchasing power preferences regarded decisions in every economic activity. Based on his thoughts, Al-Maqrizi focused on the purchasing power of the currency in the community, especially the Egyptian state at that time. Through the background of social conditions during the time he lived, a thought emerged about the purchasing power of money in society. Based on the explanation above, it can be correlated how the purchasing power of the people can be increased which is correlated with the economic conditions of a country in this modern era.

1) Currency and Stability of People's Purchasing Power

Al-Maqrizi stated that the increase in prices (inflation) due to the amount of money in circulation reduced the purchasing power of the people (Karim, 2017). An Al-Maqrizi prioritized the use of dinars and dirhams as the main transaction tools. Judging from the economic aspect, the value quality of dinars and dirhams was fixed and better than full money. The circulation of dinars and dirhams can also be more assured of supervision so that if there was an increase in the amount of money circulating in the community, it can be anticipated immediately. Reflecting on this, Bank Indonesia was launching a new currency expected not to overprint. The presence of a new currency in the community was also accompanied by a reduction in the old currency so that the amount of money in circulation did not increase. The enthusiasm and high demand of consumers in owning a new currency also need to be monitored so that no fraud sells and trades the money at high prices.

As a group of modern society, it was necessary to make wise decisions in responding to the presence of the new currency so that its circulation remains stable. The presence of innovations related to digital currencies in this modern era also provides new solutions for currency circulation in Indonesia itself to be more efficient. People in saving their funds tend to save into various savings instruments that were increasingly varied, following the concept brought by al-Maqrizi in his priority of using dinars or dirhams as the main currency. Regarding the increase in purchasing power in today's modern society, each individual was very intelligent and adapts easily to the conditions of the times, so that the purchasing power of money in society is directly proportional to the increase in the needs of modern society.

However, several things related to Al-Maqrizi's thoughts regarding money need to be reconsidered regarding its aspects by adjusting the current conditions of a country. The use of dinars 
and dirhams as the main medium of exchange cannot be fully implemented in all countries. Because the different social, cultural, and background conditions of each country and the limited resources in the process of printing the currency as well as the risks that will be faced by society if the use of dinars and dirhams is determined and generalized to each country.

2) Money Circulation and Mitigation of People's Purchasing Power

The excessive circulation of currency experienced during the Al-maqrizi period was caused by bad government. The number of actions harmed the people such as corruption, bribery, and taxes. The perceived impact was a decrease in state revenue through taxes, due to the number of workers and population continuously decreasing (Amalia, 2005). It's not just a problem of the excessive and even uneven circulation of money. The emergence of new money in society caused turmoil that arised in society regarding the desire to have and take advantage of the moment. The occurrence of excessive buying and selling of new currencies creates new problems in society that need to be addressed by the government.

Mitigation that can be done so that these incidents can be minimized was to establish effective policies. This could be in the form of government intervention, such as printing or circulating the money not in large amounts at once but gradually. The monetary economic policy can anticipate that the circulation of money will remain stable so that the purchasing power of people's money was also maintained. Another effort to mitigate people's purchasing power during an emergency was to reserve funds owned by the government in anticipation of an unpredictable natural disaster. With this provision, it was possible to better control inflation that occurs during natural disasters or unavoidable global disasters. Transparent government regarding the information on issues of value, quality of money, and quantity of money. In modern times, people had made international transactions against money so that currency circulation did not only occur in the country but also abroad, so there was a need for a special policy regarding the imposition of tax rates to stimulate people's purchasing power in the domestic and international sectors. The fruit of Al-maqrizi's thought is also an effort that the government can do by fixing the bureaucratic system, administration, and avoiding actions such as corruption, collusion, and nepotism (Parisi, 2018).

The hope was that the welfare (benefit) of the people became the main goal or priority that must be met by the government in establishing a policy both related to the issuance of money or the purchasing power of the people. So that the concept of Al-Maqrizi's economic thought based on the difficult social conditions at that time would not be repeated in the present. One form of implementation that can be done was not to misuse money which had an impact on the loss of people around and the wider community, such as selling new bills at high prices. Al-Maqrizi's thinking can also be used as a reference by the government so as not to imitate the behavior of the government during al-Maqrizi's time of profiting from the issuance of currency.

The need for improvements in the scope of government and society can help create prosperous economic conditions. There were frequent occurrences of certain events in Indonesia which were feared to disturb the level of people's purchasing power. One of the efforts to mitigate this was by maintaining an adequate supply of basic commodities during normal conditions and during natural disasters, religious holidays, and crises. So that the level of people's purchasing power was not disturbed by certain events. Al-Maqrizi said that if a country's government policy was aimed at the welfare of the people, then things that were detrimental to the general public can be addressed properly.

\section{Conclusion}

Al-Maqrizi's thinking in the economic field is identical to history by prioritizing an analysis of environmental problems or the surrounding community related to the economy. Al-Maqrizi's thoughts can be correlated to the ongoing phenomenon of managing a country's money so that it can achieve the 
welfare of the people (maslahah) as the main vision of Al-Maqrizi's economic thought. The Indonesia state in every policy on the issuance of the amount of money or the presence of a new currency, a study must be carried out first to review how much of the beneficial aspect is felt by the community.

The contribution of the Government of Indonesia is also highly expected to be able to manage money well, which includes the process of printing, circulating, and using money so that the stability of the exchange rate can be maintained. In addition, it is necessary to maintain an adequate supply of basic commodities during normal conditions as well as during natural disasters and crises to avoid a massive decline in people's purchasing power. It can be interpreted that the concept of economic thought offered by Al-Maqrizi is a concept that leads to an economic system that is moral, just, humane, and prosperous.

\section{Bibliography}

Abdullah, A. (2016). An Islamic Monetary Theory of Value and Equation of Exchange: Evidence from Egypt (696-1517). Humanomics.

Abdullah, A. (2020). The Islamic Monetary Standard: The Dinar and Dirham. International Journal of Islamic Economics and Finance Studies.

Alioucha, A. (1994). Mamluk Economics: A Study and Translation of al-Maqrizi Ighathah. Salt Lake: University of Utah Press.

Al-Maqrizi. (1988). Syudzur Al-Uqud fi Dzikir Al-Nuqud, tahqiq Muhammad Bahrul Ulum, Dar alZahra. Beirut.

Al-Maqrizi, T. A.-A. (2007). Ighatsatul Ummah Bikasyfil Ghummah. El-Haram. Ainul Madrasat wal Buhuts wal Buhuts al-Insaniyah wal Ijtima'iyah.

Amalia, E. (2005). Sejarah Pemikiran Ekonomi Islam dari Masa Klasik Hingga Kontemporer. Jakarta: Gramata Publishing.

asy-Syayyal, J. (1967). Pengantar al-Muahqqiq dalam Taqiyuddin Ahmad bin Ali al-Maqrizi. Kairo: Lajnah Ihya al-Turats al-Islamy.

Babbie, E. (2014). The Practice of Social Research, Fifth Edition. California: Wadsworth Publishing Company.

Behrens-Abouseif, D. (2018). The book in Mamluk Egypt and Syria (1250-1517); Scribes, libraries, and market. Leiden: Boston Brill.

Chamid, N. (2010). Jejak Langkah Sejarah Pemikiran Ekonomi Islam. Yogyakarta: Pustaka Pelajar.

Ghazali, A. (1991). Islamic Thinkers on Economic, Administration, and Transaction. Kuala Lumpur: Quil Publisher.

Ghazali, A. (1991). Islamic Thinkers on Economics, Administration and Transactions. Quill Publisher.

Gunarso, G. H. (2018). Pemikiran Ekonomi Al-Maqrizi. Munich Personal RePec Archive.

Hamidin, D. (2018). Teori Uang dan Inflasi dalam Analisis Pemikiran Al Maqrizi. Munich Personal RePEc Archive.

Hernaningsih, F. (2018). Pengaruh Kestabilan Inflasi dan Ketimpangan Pendapatan Terhadap Daya Beli Masyarakat. Jurnal Ilmiah M-Progress.

Huda, N. (2008). Ekonomi Makro Islam Pendekatan Teoritis. Jakarta: Kencana Pranada Media Group.

Ilman, A. H. (2001). Uang Suatu Kajian Kontemporer. Jakarta: Gema Insani Press.

Ilyas, R. (2016). Konsep Uang Dalam Perspektif Ekonomi Islam. Jurnal Bisnis dan Manajemen Islam.

Iqbal, I. (2012). Pemikiran Ekonomi Islam Tentang Uang, Harga dan Pasar. Jurnal Khatulistiwa - Jurnal Of Islamic Studies. 
Islahi, A. A. (2013). Economic and Financial Crises in Fifteenth - Century Egypt: Lessons from the History. Islamic Economic Studies.

Islam, D. R. (1999). Suplemen Ensiklopedi Islam. Jakarta: PT Ichtiar Baru Van Hoeve.

Karim, A. A. (2001). Ekonomi Islam: Suatu Kajian Kontemporer. Jakarta: Gema Insani Press.

Karim, A. A. (2017). Sejarah Pemikiran Ekonomi Islam. Depok: Rajawali Pers.

Laurence S. Moss, J. A. (1996). Historian of Economics: Perspectives on the History of Economic Thought. London: Routledge.

Mujahidin, A. (2007). Ekonomi Islam. Jakarta: PT Raja Grafindo Persada.

Nasution, M. E. (2007). Pengenalan Ekslusif Ekonomi Islam. Jakarta: Kencana Prenada Media Group.

Nazir, M. (1988). Metode Penelitian. Jakarta: Ghalia Indonesia.

Nordhaus, P. A. (2001). Ilmu Makro Ekonomi. Jakarta: PT. Media Edukasi.

Pangiuk, A. (2015). Inflasi pada Fenomena Sosial Ekonomi: Pandangan Al-Maqrizi. Kontekstualita.

Parisi, S. A. (2018). Determinan Inflasi: Pendekatan Al-Maqrizi dan Perspektif Manajemen Syariah. Islamic Economics Journal.

Suar, A. M. (2020). Al Maqrizi view on Islamic Economy and Its Relevance to Covid-19 Pandemic in Indonesia. Nurani: Jurnal Kajian Syari'ah dan Masyarakat.

Syayyal, J. A. (1967). Penghantar Al Muhaqqiq, dalam Taqiyuddin Ahmad bin Ali Al Maqrizi, Itt'azh Al-Hunafa bi Akhbar Al Aimmah Al Fathmiyyin Al Khulafa. Kairo: Lajnah Ilhya Al Turtas Al Islamy.

Vaish, M. C. (2009). Monetary Theory. New Delhi: Vikas Publishing House. 